\title{
Characterization of Klebsiella granulomatis pathogenic to silkworm, Bombyx mori $\mathrm{L}$.
}

\author{
M. K. Mohanta - A. K. Saha - D. K. M. A. Saleh • \\ M. S. Islam • K. S. B. Mannan • M. Fakruddin
}

Received: 22 July 2014/ Accepted: 30 September 2014/Published online: 19 October 2014

(C) The Author(s) 2014. This article is published with open access at Springerlink.com

\begin{abstract}
Bacterial disease of silkworm causes significant reduction of silk production leading to huge economic loss. This study aims to isolate bacteria from diseased silkworm and to determine its pathogenicity and antibiotic resistance. A strain of Klebsiella granulomatis has been isolated from silkworm haemolymph which was later identified on the basis of biochemical tests and 16S rRNA gene sequencing. The optimum culture condition of $K$. granulomatis was determined at $\mathrm{pH} 7.0$ and $37^{\circ} \mathrm{C}$ temperature. The strain was resistant to most of the antibiotics used in this study except azithromycin, gentamycin and ciprofloxacin. The strain is capable to reproduce flacherrie like symptoms with high mortality rate when re-injected into healthy silkworm. Treatment with low dose of ciprofloxacin was found to be effective to prevent flacherrie induced by the isolated K. granulomatis strain.
\end{abstract}

Keywords Silkworm · Pathogenic bacteria $\cdot$ Klebsiella pneumoniae $\cdot$ Haemolymph $\cdot$ Antibiotic

M. K. Mohanta $(\bowtie)$ - A. K. Saha - D. K. M. A. Saleh ·

M. S. Islam

Department of Zoology, Rajshahi University, Rajshahi 6205, Bangladesh

e-mail: mkmohanta_zool@yahoo.com

\section{K. S. B. Mannan}

Center for Food and Waterborne Diseases, icddr'b, Dhaka, Bangladesh

M. Fakruddin

Institute of Food Science and Technology, Bangladesh Council of Scientific and Industrial Research, Dhaka, Bangladesh

\section{Introduction}

Sericulture is an agro-based industry practiced in the greater Rajshahi, Chapai Nawabganj, Natore, Bogra and Naogaon and certain nontraditional areas in Bangladesh. It is grouped under village and small enterprises sector that plays major role for the creation of sustainable employment and income (Ishtiaque et al. 2013). The poor people of the society, the landless, and the poor woman in particular, can be involved in sericulture activities. According to an estimate, livelihood of about 0.1 million people in Rajshahi region is directly or indirectly involved with sericulture industry (Islam et al. 2004).

The mulberry silkworm, Bombyx mori, has been domesticated for silk production for more than 5,000 years and provides the major source of income for 30 million families. Geographically, Asia is the main producer of mulberry silk in the world and produces over $98 \%$ of the total global output (Savithri et al. 2013). During the silkworm rearing, the silkworm comes into contact with pathogenic agents (viz. Protozoa-microsporidians, virus, Fungi and Bacteria) which accounts for considerable loss to cocoon production (Samson 1995). Rearing silkworm free from diseases is a major constraint to silkworm rearers (Priyadharshini et al. 2008). About $34-40 \%$ the total crop in a year has been reported to be loss due to diseases (Sheebha et al. 2008).

Bacterial diseases are of common occurrence in Bangladesh. Prevalence of bacterial infection in plant and insect is high due to elevated temperature (above $30{ }^{\circ} \mathrm{C}$ ) and low relative humidity (below $80 \%$ ). Bacterial flacherrie is a common disease of mulberry silkworm (kaito et al. 2002). The aetiology of bacterial diseases is not fully understood because of the multiplicity of bacterial types involved in bacterial infections (Choudhury et al. 2002). 
Insects infected with pathogenic bacteria exhibit symptoms such as loss of apetite, diarrhea, vomitting, larvae softening and foul odor upon death (Singh et al. 2011, Sakthivel et al. 2012).

From economic point of view, this disease is of particular concern as it's prevalence mostly is in theripen mounted worms and it cause death within $24 \mathrm{~h}$ (Rahmathulla 2012). Since there are no specific preventive measures for the occurrence and spread of disease other than sanitized rearing methods, the only commercial practice today is to discard large stocks of worms in case of infection to avoid the spread of disease (Acharya et al. 2002). Antibiotics are widely used in sericulture industry as a component of bed disinfectants and as therapeutic applications against bacterial diseases (Subramanian et al. 2009). Broad spectrum antibiotics viz., penicillin, streptomycin, tetracycline and chloramphenicol were already tried on silkworm and found successful (Venkatesh and Srivastava 2010). Antibiotics in silkworm are approved for four different purposes: disease treatment, disease prevention, disease control and health maintenance or growth promotion (Phillips et al. 2004).

The aim of this study was to isolate pathogenic bacteria from diseased silkworm, to determine the pathogenicity of the isolated bacterium and to evaluate the therapeutic effects of antibiotics on the pathogen.

\section{Materials and methods}

\section{Collection of silkworms}

Diseased silkworm larvae were collected from Bangladesh Sericulture Research and Training Institute (BSRTI), Rajshahi. They were then used as a source of inocula for the isolation of the pathogenic microorganisms.

Isolation and characterization of the microbes

from the diseased silkworms

The microbes were isolated from silkworm haemolymph. One loopful of haemolymph was directly transferred into nutrient broth media (Hi Media, India), which was incubated for 2 days at $37{ }^{\circ} \mathrm{C}$ and subjected to shaking at $120 \mathrm{rpm}$ on an orbital shaker. Control flasks without inoculates were also prepared and incubated at $37{ }^{\circ} \mathrm{C}$ with an orbital shaker. The cultures that were found turbid after a period of 0 up to 2 days were used as inocula in subsequent experiments.
Microscopic examination and identification of bacterial cells

For the identification of the pathogenic bacterium, morphological characterizations, microscopic observations, growth characteristics, biochemical tests and antibiotic sensitivity tests were performed. The microorganisms were identified according to Bergey's Manual of Systematic Bacteriology (Holt 2005).

Identification of the pathogen by $16 \mathrm{~S}$ rRNA gene sequence

Genomic DNA of the bacterial isolate was isolated according to Mohanta et al. (2012). Gene fragments specific for the highly variable region of the bacterial $16 \mathrm{~S}$ rRNA gene were amplified by PCR using universal PCR primer as described by Loffler et al. (2000) (Sigma, USA) in a thermal cycler (MJ Research Inc., Watertown, USA). The sequence of the forward primer was $16 \mathrm{SF} 5^{\prime}$-GAGT TTGATCCTGGCTCAG- $3^{\prime}$ and the sequence of the reverse primer was 16SR 5'-GAAAGGAGGTGATCCAGCC-3'. The PCR products were subjected to $1 \%$ agarose gel electrophoresis, stained with ethidium bromide and visualized on a UV transilluminator for the presence of about 1,500 bp PCR products. Amplified 16S rRNA gene PCR products were purified using StrataPrep PCR purification kit (Stratagene, USA) according to the manufacturer's protocol. Sequencing reactions were carried out using ABIPrism Big dye terminator cycle sequencing ready reaction kit and the PCR products were purified by a standard protocol. The purified cycle sequenced products were analyzed with an ABIPrism 310 genetic analyzer. The chromatogram sequencing files were edited using Chromas 2.32. The homology of the $16 \mathrm{~S}$ rRNA gene sequences was checked with the 16S rRNA gene sequences of other organisms that had already been submitted to GenBank database using the BLASTN (http://www.ncbi.nih.gov/ BLAST/) algorithm.

Effect of temperature and $\mathrm{pH}$ on bacterial growth

Temperature and $\mathrm{pH}$ influence bacterial growth. For the effect of $\mathrm{pH}$, culture medium (nutrient broth, Hi-media) was adjusted to $\mathrm{pH}$ 5.0, 7.0, and 8.0. Incubation temperature was varied at, 25, 30 and $37{ }^{\circ} \mathrm{C}$. Bacterial cell density of liquid cultures was determined by measuring optical density at $660 \mathrm{~nm}$ with photoelectric colorimeter (AE-11 M, Erma Inc., Tokyo) (Mohanta et al. 2012). 
Pathogenicity of the isolate to silkworm

Larvae of hybrid strain B. mori were reared at $25{ }^{\circ} \mathrm{C}$. Fresh mulberry leaves (average size: $10,20 \mathrm{~cm}$ ) were obtained from a garden of mulberry, Department of Zoology, University of Rajshahi. The isolated bacterium was cultured for $24 \mathrm{~h}$ in nutrient broth and harvested by centrifuge and re-suspended in phosphate buffered saline and cell count was determined and diluted with PBS. Fifty healthy newly moulted fifth-instar larvae were included in each experimental group. Mulberry leaves inoculated with appropriate number of the bacterium were fed to the larvae two times a day. Symptoms of the diseases were observed and mortality rate was recorded each day. Statistical analysis was completed using SPSS 16.0, and the median lethal concentration (LC50) and regression equations were obtained.

Determination of pathogenicity of the isolated bacterium against silkworm

Two treatments were used to investigate the effects of ciprofloxacin on pathogenicity of the isolate against silkworm.

Treatment 1 Third instars of healthy silkworm larvae were selected for the experiment. Ten larvae from each group were considered for the treatment. Fresh broth culture of the isolated bacterium at $10^{7} \mathrm{cfu} \mathrm{mL}^{-1}$ was spread or smeared on mulberry leaves and fed to the 3rd instar larvae two times in a day. The shape, size and weight of the cocoon were recorded.

Treatment 2 Fresh broth culture of the test bacterium at $10^{7} \mathrm{cfu} . \mathrm{mL}^{-1}$ were smeared on mulberry leaves and fed to the 3rd instar larvae. In the same time an antibiotic (ciprofloxacin at $20 \mu \mathrm{l} / \mathrm{gbw}$ ) was injected into the gut of the larvae with the help of micro injection (needle size $\left.0.30 \times 8 \mathrm{~mm} / 30 \mathrm{G} \times 5 / 16^{\prime \prime}\right)$ two times a day for getting cure of the disease. The treatment was carried out up to pupation of the larvae. The shape, size and weight of the cocoon were recorded.

\section{Results}

Isolation and identification of the bacterium

Bacteria were isolated by plating onto an agar solidified nutrient medium. The plates were incubated at $37^{\circ} \mathrm{C}$ for 2 days and bacterial colonies were found to grow on the medium. Results of microscopic analysis of bacterial cells and their growth characteristics are presented in Table 1 while the biochemical and antibiotic sensitivity tests of the bacterium are presented in Table 1, 2, respectively. Isolated bacterial strain was identified by both morphological
Table 1 Cultural characteristics and microscopic observations of the isolated bacterial strain

\begin{tabular}{lll}
\hline Agar plates & Characters & Results \\
\hline Nutrient agar slant & $\begin{array}{c}\text { Abundance of } \\
\text { growth } \\
\text { Colour }\end{array}$ & Moderate \\
& Appearance & $\begin{array}{l}\text { Creamy White } \\
\text { Uniform with fine } \\
\text { turbidity }\end{array}$ \\
Microscopic observations & Gram staining & Gram-negative \\
& Motility & Motile \\
MacConkey & Appearance & Mucoid \\
& Colour & Pink \\
XLD & Colour & Yellow \\
\hline
\end{tabular}

Table 2 Biochemical test results for the isolated bacterial strain (K. granulomatis)

\begin{tabular}{llll}
\hline Biochemical test & Reaction & Sugar utilization & Reaction \\
\hline Catalase & + & Glucose & + \\
Oxidase & + & Arabinose & - \\
Nitrate reduction & - & Lactose & + \\
Indole & - & Xylose & + \\
Methyl Red & - & Malonate & + \\
VP & + & Rhamnose & + \\
Lysine decarboxylase & + & Raffinose & - \\
Citrate & + & Glucose & + \\
Urease & + & Arabinose & - \\
$\mathrm{H}_{2} \mathrm{~S}$ production & - & Lactose & + \\
$\beta$-galactosidase & + & Dulcitol & - \\
\hline
\end{tabular}

$(+=$ microbial growth, $-=$ no growth $)$

and biochemical tests and this was further confirmed by $16 \mathrm{~S}$ rRNA gene sequence analysis. The strain showed $100 \%$ homology with Klebsiella granulomatis. The sequence was deposited in genbank with accession noKM593690 (BankIt1760483 Klebsiella).

Effect of temperature and $\mathrm{pH}$ on bacterial growth

To verity the effects of temperature and $\mathrm{pH}$ of growth medium on the growth rate of the bacterium, a series of investigations were carried out which are presented in Figs. 1, 2, respectively. The optimum $\mathrm{pH}$ for the growth of the isolate was 7.0 and extreme $\mathrm{pH}$ (5.0 and 8.0) restricted the bacterial growth (Fig. 1). The highest growth rate was observed in the bacterium. The optimum temperature for the growth of bacterium was found at $37{ }^{\circ} \mathrm{C}$ and the extreme temperatures between 30 and $25^{\circ} \mathrm{C}$ restricted the bacterial growth. At $37{ }^{\circ} \mathrm{C}$ the rate of the best growth was found to be the highest $(\mathrm{OD}=0.33)$ after $16 \mathrm{~h}$ of culture and after $18 \mathrm{~h}$ the OD started to decrease (Fig. 2). 
Fig. 1 Effects of $\mathrm{pH}$ on bacterial growth

Fig. 2 Effects of temperature on bacterial growth
Effect of $\mathrm{pH}$ on growth of $K$. granulomatisisolate

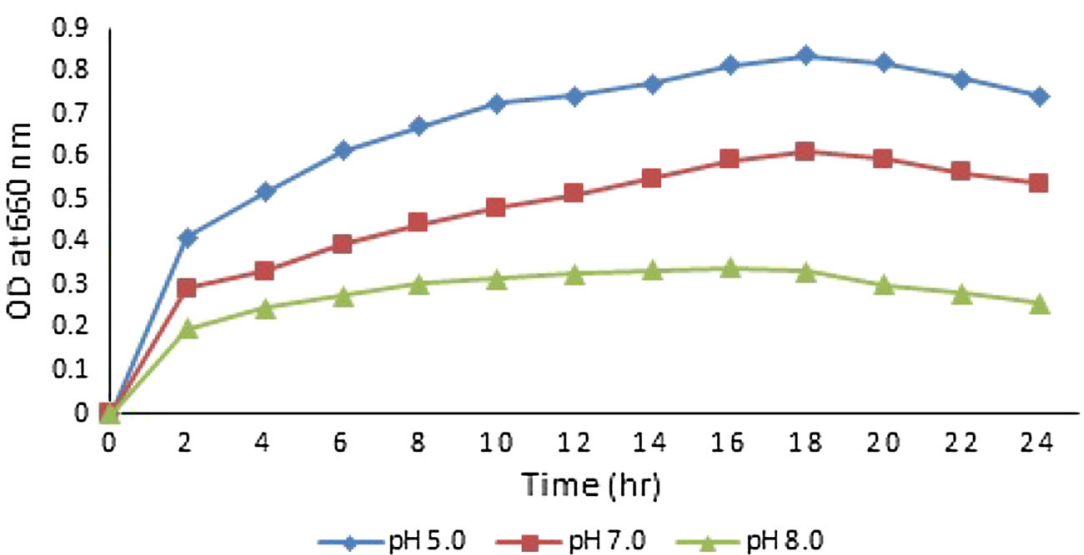

Effect of temperature of growth of $K$. granulomatis isolate

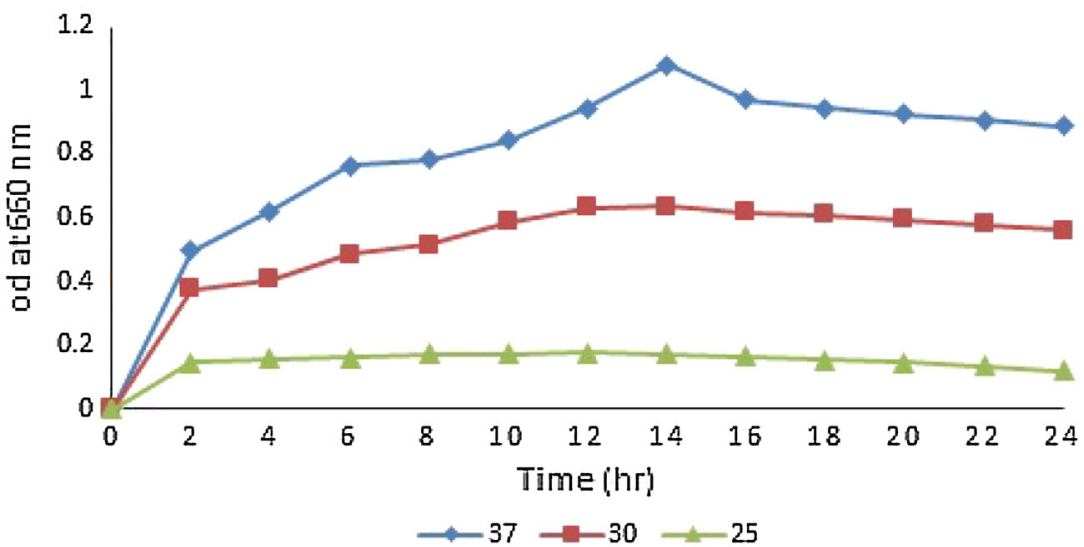

Table 3 Antibiotic sensitivity tests

\begin{tabular}{lcll}
\hline Antibiotics & Disc distance $(\mathrm{mm})$ & $\mathrm{R}$ & $\mathrm{S}$ and I \\
\hline Vancomycin & 5 & $\mathrm{R}$ & - \\
Pefloxacin & 12 & - & $\mathrm{I}$ \\
Cefuroxime sodium & 5 & $\mathrm{R}$ & - \\
Penicillin & 5 & $\mathrm{R}$ & - \\
Cephardine & 5 & $\mathrm{R}$ & - \\
Mecillinam & 5 & $\mathrm{R}$ & - \\
Nitro furantoin & 5 & $\mathrm{R}$ & - \\
Vancomycin & 5 & $\mathrm{R}$ & - \\
Azithromycine & 18 & - & $\mathrm{S}$ \\
Gentamycin & 16 & - & $\mathrm{S}$ \\
Ciprofloxacin & 16 & - & $\mathrm{S}$ \\
\hline
\end{tabular}

$(5-10 \mathrm{~mm})=$ Resistant to antibiotics $(\mathrm{R}) ;(15-20 \mathrm{~mm})=$ Sensitive to antibiotic $(\mathrm{S}),(10-15 \mathrm{~mm})=$ intermediate resistance $(\mathrm{I})$

Antibiotic susceptibility of the isolate

The isolate showed resistance against seven antibiotics included in this study (Table 3). Only azithromycin,
Table 4 Pathogenicity of the Klebsiella granulomatis isolate against silkworm

\begin{tabular}{llll}
\hline $\begin{array}{l}\text { Concentration of } \\
\text { bacteria }(\mathrm{cfu} / \mathrm{mL})\end{array}$ & $\begin{array}{l}\text { Corrected } \\
\text { mortality }(\%)\end{array}$ & LC $_{50}$ & $\begin{array}{l}\text { Pearson } \\
\text { correlation }\end{array}$ \\
\hline $10^{4}$ & 21.36 & $2.54 \times 10^{7}$ & 0.924 \\
$10^{5}$ & 37.25 & & \\
$10^{6}$ & 61.33 & & \\
$10^{7}$ & 92.43 & & \\
\hline
\end{tabular}

gentamycin and ciprofloxacin were found to be effective against the isolate.

Determination of pathogenicity of the isolated bacterium

The isolate was found to be pathogenic to Bombyx mori as it induces bacterial flacherrie like symptoms upon being infected by the larvae. The silkworms infected with the isolate exhibited symptoms similar to those of bacterial flacherrie as described by Zhang et al. (2013). Mortality 
Table 5 Effect of ciprofloxacin treatment on the cocoon traits in B. mori

\begin{tabular}{|c|c|c|c|c|c|c|c|c|c|}
\hline SL & $\mathrm{Wt}^{\mathrm{a}}$ & $\mathrm{Wt}^{\mathrm{b}}$ & $\mathrm{Wt}^{\mathrm{c}}$ & $\mathrm{Lt}^{\mathrm{a}}$ & $\mathrm{Lt}^{\mathrm{b}}$ & $\mathrm{Lt}^{\mathrm{c}}$ & $\mathrm{Wd}^{\mathrm{a}}$ & $\mathrm{Wd}^{\mathrm{b}}$ & $\mathrm{Wd}^{\mathrm{c}}$ \\
\hline 1 & 0.91 & 1.08 & 1.18 & 3.10 & 3.40 & 4.57 & 4.60 & 5.60 & 5.98 \\
\hline 2 & 0.86 & 1.04 & 1.21 & 3.50 & 4.30 & 4.62 & 4.30 & 5.90 & 5.89 \\
\hline 3 & 0.84 & 1.07 & 1.19 & 3.00 & 3.20 & 4.39 & 4.40 & 5.60 & 5.88 \\
\hline 4 & 0.87 & 1.12 & 1.23 & 3.40 & 3.90 & 4.29 & 4.60 & 6.10 & 5.93 \\
\hline 5 & 0.62 & 1.06 & 1.22 & 3.50 & 4.10 & 4.44 & 4.10 & 5.30 & 5.79 \\
\hline 6 & 0.84 & 1.02 & 1.23 & 3.30 & 3.60 & 4.39 & 4.20 & 5.30 & 5.82 \\
\hline 7 & 0.94 & 1.11 & 1.19 & 2.90 & 3.90 & 4.51 & 4.30 & 5.40 & 5.88 \\
\hline 8 & 0.85 & 1.10 & 1.20 & 3.10 & 3.80 & 4.49 & 4.90 & 5.20 & 5.91 \\
\hline 9 & 0.94 & 1.08 & 1.17 & 3.10 & 3.70 & 4.29 & 4.70 & 5.20 & 5.83 \\
\hline 10 & 0.88 & 1.04 & 1.18 & 3.00 & 3.60 & 4.31 & 4.20 & 5.10 & 5.94 \\
\hline Mean \pm SD & $0.855 \pm 0.09$ & $1.07 \pm 0.03$ & $1.2 \pm 0.02$ & $3.19 \pm 0.22$ & $3.75 \pm 0.32$ & $4.42 \pm 0.11$ & $4.43 \pm 0.26$ & $5.47 \pm 0.33$ & $5.88 \pm 0.05$ \\
\hline
\end{tabular}

Cocoon weights are in $\mathrm{g}$, lengths and widths are in $\mathrm{mm}$

$W t$ weight, $L t$ Length, $W d$ width

a Diseased silkworm treated with no antibiotics

b Diseased silkworm treated with antibiotic

c Non-diseased silkworm

rate of the larvae was increased with increasing bacterial concentration. LC50 was found to be $2.54 \times 10^{7}$ (Table 4).

Effect of ciprofloxacin on larvae infected with the isolate

It was found that the production of cocoon as well as the weight, length and width in the control (only bacteria, no antibiotic) and antibiotic-injected groups vary significantly (Table 5). Weight, length and width of the cocoon treated with ciprofloxacin had better weight, length and width indicating that ciprofloxacin can be used to control flacherrie caused by $K$. granulomatis as well as by other bacteria.

\section{Discussion}

The economic status of Bangladesh mainly depends on agriculture. Silk manufacturing is the traditional occupation in Rajshahi, Bangladesh. Many people earn their lively hood by silkworm rearing. During silkworm rearing, the silkworm comes into contact with various pathogenic bacteria. About 34 to $40 \%$ of total crop in a year has been reported to be lost due to diseases like flacherie. Bacterial flacherie in silkworm is known to be caused by consortium of various pathogeinc bacteria.

In this study the microorganism was identified as a number of the genera Klebsiella granulomatis bacterium. Physiological and biochemical tests revealed that the microorganism was gram-negative, rod-shaped and nonmotile bacterium. After a $16 \mathrm{~S}$ rRNA gene sequencing and
BLAST search, $99 \%$ similarity was observed with Klebsiella granulomatis. Optimum $\mathrm{pH}$ and temperature for growth of the isolate was found to be 7 and $37^{\circ} \mathrm{C}$, respectively.

Many previous studies reported isolation of bacteria of different genus from diseased silkworm, such as, Acrobacter cloacae, Achromobacter superficialis, Achromobacter delmarvae, Pseudomonas boreopolis, Pseudomonas ovalis, Escherichia freundii and Staphylococcus albus (Chitra et al. 1973); Bacillus subtilis, Bacillus cereus, Staphylococcus albus, Stabhylococcus aureus and Klebsiella cloacae (Priyadharshini et al. 2008); Streptococcus faecalis (Patil 1994), Bacillus thuringienisis (Nataraju et al. 1991), Streptococcus spp. Serratia spp. and Bacillus spp. (Anitha et al. 1994); Pseudomonas chlororaphis (Tao et al. 2011) and Providencia rettgeri (Zhang et al. 2013). The occurrence of Klebsiella granulomatis, gram negative bacilli in the silkworm haemolymph is being reported for the first time through this study.

Antibiotics are used to find out their effectiveness against pathogenic bacteria (Mahmoud et al. 2012). As a result, bacteria associated with silkworm are prone to develop resistance to commonly used antibiotics. Eleven types of antibiotic were used in this study and only three antibiotics viz. azithromycine, gentamycin and ciprofloxacin were showed strongly effective against the isolated bacterium. This high antibiotic resistance of the bacterium associated with flacherrie indicates reduced usability of current antibiotics. Similar antibiotic resistance of bacteria associated with flacherrie has been reported by many previous studies (Nahar 1995, Kim et al. 2002). 
Mortality rate increased with increased bacterial dose. At $\sim 10^{4} \mathrm{cfu} / \mathrm{ml}$ bacterial dose mortality rate was $21.36 \%$, at $\sim 10^{5} \mathrm{cfu} / \mathrm{ml} 37.25 \%$, at $\sim 10^{6} \mathrm{cfu} / \mathrm{ml} 61.33 \%$ and at $\sim 10^{7} \mathrm{cfu} / \mathrm{ml}$ mortality rate was $92.43 \%$. LC50 was found to be $2.54 \times 10^{7}$ with pearson correlation 0.924 .

Antibiotics improve feed consumption and growth by stimulating metabolic processes within the silkworm as well as reduce the occurrence of diseases which causes immense loss to sericulture industry. It was found that ciprofloxacin significantly increases the effective rate of rearing and cocoon weights and cocoon length and width were significantly increased under the effects of antibiotic treatment comparing with control. Similar effect by gentamycin was reported by Mahmoud et al. (2012). Use of antibiotic to prevent bacterial disease of silkworm has also been reported by many studies (Hamamoto et al. 2005, Kaito et al. 2002).

Administration of antibiotics and dose of administration are critical as in many cases administration of antibiotics was reported to have detrimental effects on intestinal micro-flora of silkworms which cause adverse effects on the physiological system (Subramanian et al., 2009). As a result, it is recommended to apply low concentration of antibiotics to induce prophylactic measures to prevent bacterial infections, as also recommended by other researchers (Sheebha et al. 2008, Anandakumar et al. 2012).

\section{Conclusion}

This study reports for the first time about bacterial flacherrie infection of silkworm in Bangladesh and K. granulomatis was found to be a causative bacterium of flacherrie disease. Knowledge on causative bacteria, pathogenic potential and antibiotic resistance is important to deduce an effective treatment strategy. Results of this study in combination with previous study results stress the need for more extensive research focusing on prevention and control of bacterial flacherrie disease of silkworm of Bangladesh.

Acknowledgments The authors acknowledge the support of Bangladesh Sericulture Research and Training Institute (BSRTI), Rajshahi, while conducting the study.

Conflict of interest The authors declare that they have no conflict of interests.

Open Access This article is distributed under the terms of the Creative Commons Attribution License which permits any use, distribution, and reproduction in any medium, provided the original author(s) and the source are credited.

\section{References}

Acharya A, Sriram S, Schrawat S, Rabman M, Sehgal D, Gopinathan KP (2002) Bombyx mori nucleopolyhedrovirus: molecular biology and biotechnological applications for large-scale synthesis of recombinant proteins. Curr Sci 28:455-465

Anandakumar MD, Michael S, Ananthanarayana SR (2012) Effect of application of amoxicillin and ampicillin on the commercial parameters of silkworm Bombyx mori L. Intl J Environ Res $1(1): 1-4$

Anitha T, Sironmani P, Meena P, Vanitha R (1994) Isolation and characterization of pathogenic bacterial species in the silkworm, Bombyx mori L. Sericologia 34(1):97-102

Chitra C, Bhandarkar A, Karanth NGK, Vasantharajan VN (1973) Studies on sappe disease of silkworm, Bombyx mori L. Isolation and characterization of pathogenic bacteria from diseased silkworms. Curr Sci 42(11):373-376

Choudhury A, Guba A, Yadav A, Unni B, Roy M (2002) Causal organism of flacherie in the silkworm Antheraea assama Ww: isolation, characterization and its inhibition by garlic extract. Phytother Res 16:89-90

Hamamoto H, Kurokawa K, Kaito C, Kamura K, Marntra RI, Kusuhara H, Santa T, Sekimizu K (2005) Quantitative evaluation of the therapeutic effects of antibiotics using silkworm as an animal model. Res Adv Antimicrob Agents Chemother 5:1-23

Holt JG (2005) Bergey's manual of systematic bacteriology, vol 2. Sringer, New York

Ishtiaque A, Haider F, Rafi MH, Mahmud MS, Uddin MH, Habiba U (2013) The plight of the Bangladeshi silk industry: an empirical investigation. Mal J Soc Space 9(2):9-16

Islam MR, Ali MAO, Paul DK, Sultana S, Banu NA, Islam MR (2004) Effect of salt, nickel chloride supplementation on the growth of silkworm, Bombyx mori L. (Lepidoptera: bombycidae). J Biol Sci 4(2):170-172

Kaito C, Akimitsu N, Watanabe H, Sekimii K (2002) Silkworm larvae as an animal model of bacterial infection pathogenic to humans. Microbial Path 32(4):183-190

Kim G, Park Y, Kim Y (2002) Identification of a pathogenic bacterium, Staphylococcus gallinarum, to Bombyx mori. Korean J Appl Entomol 41(4):279-284

Loffler FE, Sun Q, LI J, Tiedje JM (2000) 16 s rRNA gene-based detection of tetrachloroethene dechlorinating desulfuromonas and dehalococcoides species. Appl Env Microbiol 66:1369-1374

Mahmoud MS, Rehab HT, Saad IAI (2012) Antibiotic (Gentamicin) impact on bacterial Flacherrie disease of silkworm, Bombyx mori L. Egypt Acad J Biol Sci 5(2):55-63

Mohanta MK, Saha AK, Zamman MT, Ekram AE, Khan AE, Mannan SB, Fakruddin M (2012) Isolation and characterization of carbofuran degrading bacteria from cultivated soil. Biochem Cell Arch 12(2):313-320

Nahar A (1995) In vitro screening of some disinfectants and antibiotics against Serratia morcesecns (Bizio). Bull Sericul Res 6:79-83

Nataraju B, Balavenkatasubbaiah M, Baig M, Singh BD, Sengupta K (1991) A report on the distribution of bacillus thuringiensis in sericultural areas of Karnataka. India Indian $\mathrm{J}$ Sericul 30(1):56-58

Patil CS (1994) New record of a bacteria pathogen, Streptococcus faecalis Andrews and Horder, on mulberry silkworm Bombyx mori L. from India. Sericologia 34:54-55

Phillips I, Casewell M, Cox T, Groot B, Friis C, Jones I, Nightingale C, Preston R, Waddell J (2004) Does the use of antibiotics in food animals pose a risk to human health? A critical review of published data. J Antimicrob Chemo 53(1):28-52 
Priyadharshini P, Mahalingam CA, Shashidhar KR (2008) Identification and Characterization of bacterial Pathogens in silkworm Bombyx mori L. Cur Biotica 2(2):181-192

Rahmathulla VK (2012) Management of climatic factors for successful silkworm (Bomyx mori L.) crop and higher silk production: A review. Psyche article ID 121234

Sakthivel S, Angaleswari C, Mahalingam PU (2012) Isolation and identification of bacteria responsible for flacherie in silkworms. Adv Appl Sci Res 3(6):4066-4068

Samson MV (1995) Flacherie in Bombyx mori L. Indian Silk 33(11):31-32

Savithri G, Sujathamma P, Krishna VA (2013) Silkworm Bombyx mori-An economic insect. Intl J Sci Res 2(7):535-537

Sheebha A, Quraiza F, Mdfhilsath, Manohar D, Sam S, Bai R (2008) Effect of prophylactic antibiotic treatment on the growth and cocoon characteristics of Bombyx mori L. J Basic Appl Biol 2(1):19-22
Singh GP, Sinha AK, Kumar PK, Prasad BC (2011) Characterization and identification of bacteria infecting indian tropical tasar silkworm Antheraea mylitta D. Res J Microbiol 6(12):891-897

Subramanian S, Mohanraj P, Muthuswamy M (2009) New paradigm in silkworm disease management using probiotic application of Streptomyces noursel. Karnataka J Agri Sci 22(3):499-501

Tao H-P, Shen Z-Y, Zhu F, Xu X-F, Tang X-D, Xu L (2011) Isolation and identification of a pathogen of silkworm Bombyx mori. Curr Microbiol 62:876-883

Venkatesh KR, Srivastava A (2010) Relevance of antibiotics with reference to sericulture industry. Intl J Sci Nat 1(2):97-100

Zhang J, Shen Z, Tang X, Xu L, Zhu F (2013) Isolation and identification of a pathogen, Providencia rettgeri, in Bombyx mori. Global J Bacteriol Cytol Nematol 1(1):49-55 